\title{
DÜBLIN
}

Technological University Dublin

ARROW@TU Dublin

2020-06-19

\section{Questions Concerning Attention and Stiegler's Therapeutics}

\author{
Noel Fitzpatrick \\ Technological University Dublin, noel.fitzpatrick@tudublin.ie
}

Follow this and additional works at: https://arrow.tudublin.ie/gradcamart

Part of the Continental Philosophy Commons, Digital Humanities Commons, Epistemology Commons, and the Philosophy of Science Commons

\section{Recommended Citation}

Noel Fitzpatrick (2020) Questions concerning attention and Stiegler's therapeutics, Educational Philosophy and Theory, 52:4, 348-360, DOI: 10.1080/00131857.2019.1625330

This Article is brought to you for free and open access by the Graduate School of Creative Arts and Media at ARROW@TU Dublin. It has been accepted for inclusion in Articles by an authorized administrator of ARROW@TU

Dublin. For more information, please contact

arrow.admin@tudublin.ie, aisling.coyne@tudublin.ie, gerard.connolly@tudublin.ie.

Funder: Marie-Curie

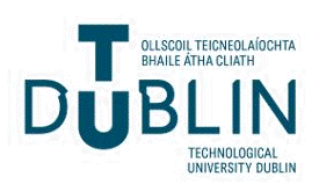




\section{Educational Philosophy and Theory}

\section{Questions concerning attention and Stiegler's therapeutics}

\section{Noel Fitzpatrick}

To cite this article: Noel Fitzpatrick (2020) Questions concerning attention and Stiegler's therapeutics, Educational Philosophy and Theory, 52:4, 348-360, DOI: 10.1080/00131857.2019.1625330

To link to this article: https://doi.org/10.1080/00131857.2019.1625330

曲 Published online: 11 Jun 2019.

Submit your article to this journal $\widetilde{T}$

山 Article views: 68

Q View related articles $\widetilde{ }$

View Crossmark data $\nearrow$ 


\title{
Questions concerning attention and Stiegler's therapeutics
}

\author{
Noel Fitzpatrick \\ Graduate School of Creative Arts and Media Technological University Dublin, Dublin, Ireland
}

\begin{abstract}
The article sets out to develop the concept of attention as a key aspect to building the possible therapeutics that Bernard Stiegler's recent works have pointed to (The Automatic Society, 2016, The Neganthropocene, 2018 and Qu'appelle-t-on Panser, 2018). The therapeutic aspect of pharmacology takes place through processes that are neganthropic; therefore, which attempt to counteract the entropic nature of digital technologies where there is flattening out to the measurable and the calculable of Big Data. The most obvious examples of this flattening out can be seen in relation to the use of natural language processing technologies for text interpretation and the use of text analytics alongside student analytics. However, the process of exosomatisation of knowledge takes place in forms of hypomnesic tertiary retentions or digital technologies. The loss of knowledge is inherent to these processes of exteriorisation, this loss of knowledge takes place through a process proletarianisation which Marx had pointed to in the Grundisse (1939). The therapeutic gesture is, therefore, an intrinsically educational one, where the loss of knowledge of the pharmacological nature of digital technologies is counteracted by other forms of knowledge construction that can be enabled by digital technologies. Hence, there is a profound educational gesture necessary to enable the re-harnessing of technology to enable the therapeutics. This paper will argue that the positive re-harnessing, the therapeutics, can take place through the development of new forms of neganthropic gestures which can be afforded by the development of specific forms of digital technologies. These also enable a contributive research process whereby the rationalisation of the production of knowledge within the university can be challenged by collaborative, interpretative processes of knowledge production.
\end{abstract}

\section{ARTICLE HISTORY}

Received 28 November 2018

Accepted 17 May 2019

\section{KEYWORDS}

Attention; tertiary

atttention; pharmacology;

therapeutics

\section{Introduction: the question concerning attention}

Questions concerning education are raised throughout the vast work of Bernard Stiegler, from his early work on Technics and Time vol (1994) to his most recent publications on Que'-appelle-ton Panser? 1: L'immense regression (2018). The questions concerning education are raised sometimes directly, for example, in Etats de Choc bêtise et savoir au 21ème siècle (2012) Stiegler poses the question of knowledge in relation to the role of the university in the twenty-first century and the question of systemic stupidity in the information age. However, sometimes the question of education is raised more indirectly, for example, in the examination of the role of the amateur 
in La Misère Symbolique 1: L'époque hyperindustrielle, (2004). Indeed, the Latin origins of education as educere and educare, with its double semantics of caring and transferring knowledge, are both mobilised within Stiegler's propositions for the development of new forms of knowledge and education. ${ }^{1}$

In relation to questions concerning education there is one underlying current throughout the prolific work of Bernard Stiegler that is the question of attention. For Stiegler the question of attention is embedded within the 'becoming human', and by extension in the development of modes of mediation (as forms of memory) in the world through forms of digital tertiary retention. The question of attending, or giving attention to, or being called to attend to, is a question at the very core of phenomenology. There is an intrinsic relation between attending and intentionality in the work of Edmund Husserl: the world calls on me to attend it and it is this calling to attend that it is in itself a form of intentionality. However, in this brief article, there is not enough space to explore the problematic within phenomenology, nonetheless, it is important to point out that the distinctions made between the modes of attention and intentionality in the work of Husserl have been a point of much debate within contemporary phenomenology (Moran, 2000). Notwithstanding, Husserl's analysis does make a distinction between forms of attention as modes of retention, ${ }^{2}$ Husserl refers to primary (memory) retention and secondary (memory) retention. Husserl gives the example of the musical note, I perceive the note as a primary retention, and it is only in hearing the second note that the memory of the 1st perception enables a distinction between the first and the second. ${ }^{33}$ Bernard Stiegler develops the term 'tertiary retention', a tertiary retention is the external inscription of the secondary retention, this external placeholder holds the inscription of the primary and secondary retention, this could be technical device which enables the primary and secondary to be remembered. To continue with the example of music, the music is recorded (analogue or digital) and then can be repeated/represented ad infinitum. It is tertiary retention which is, arguable, the most relevant for the question of education today.

The question of education, therefore, is posed within Bernard Stiegler's work through the disruption to attention and attentional processes which are caused by digital tertiary retentions. The question concerning attention is one of the key issues facing education today, education here understood as formal and informal education from early childhood care/education to doctoral studies. The question of capturing, holding and developing attention is at the core of the very process of education itself but as Stiegler points out attention has now become the basis of the hyper-capitalist system where our attention has become the basis for the economy and financial profits of Google, Amazon, Facebook and Apple. ${ }^{4}$ These four companies now represent trillion dollar businesses whose growth is based upon, amongst other things, our ability to attend, and it is this ability to attend which is part of the very process of becoming human. The process of exploiting our attentional being in the world has led to the destruction of the very forms of attention that are being harvested. Indeed, Stiegler's states in States of Shock that the responsibility of the university is to reconstruct profound attention ${ }^{5}$ :

... the mission of universities is to reconstruct deep attention. It is to reconstruct deep attention in an age in which a global mnemotechnical system is placing psycho-technologies under the hegemonic control of marketing, the effects of which are highly toxic (effects that the manifesto on the digital humanities referred to previously does not seem to take sufficiently into account), even if some curative effects also occur (p. 171).

The reconstruction of deep attention has to happen in a period of time when attention has become a rare resource in itself, when mnemonic devices are calling on us to attend in very specific ways through exploiting desires and the satisfaction of desires what Stiegler refers to as the libidinal economy. ${ }^{6}$ This economy is built predominantly through the omnipresence of one mode of attention that of consumer desire or potential consumer desire. Our attention, our ability to attend which generates traces as data has become a commodity in itself for the hyper- 
capitalist system of world-wide exchange and transfer of data. The attention economy ${ }^{7}$ is now beginning to reach its limits where the $24 / 7$ attention is becoming more and more difficult to sustain and where desire itself is becoming exhausted. The exploitation of attention and the subsequent loss of attention points to the negative aspects of the pharmakon. Before undertaking the pharmacological analysis, which will be explored in the second part of this article, it is imperative to understand that for Bernard Stiegler to be educated is to gain knowledge and to educate is to transfer or transmit knowledge as well as to 'care'.

In the first part of this article the question of different forms of attention will be addressed, the second part will explore in more detail the relationship between the pharmacological aspect of digital technologies and their effects on attention and finally in the third part of the article the possible solutions will be examined, possible alternative modes of re-harnessing attention and re-harnessing technologies.

\section{Part one: different types of knowledge}

For Bernard Stiegler knowledge is understood not just as cognitive ability, nor simply reduced to a taxonomy of cognitive processes, but is a much wider conceptualisation of different knowledge types. For Bernard Stiegler there are three kinds of knowledge, which are not subsets but equal partners, 'savoir faire', 'savoir vivre' and 'savoir théorique'. The 'savoir faire' and the 'savoir vivre' are forms of 'know how' and 'know how-to-live' and the 'savoir théorique' translated as 'theoretical knowledge' which could be understood as a form of 'know what'. It is within this distinction between 'savoir faire', 'savoir vivre' and 'savoir théorique' that a major difference is made by Stiegler: the difference is one of calculation. For Stiegler the 'know how' and the 'know how to live' cannot be discretised and, therefore, cannot be reduced to calculation.

I speak here of all forms of knowledge, know-how-to-live, know how to do and theoretical knowledge, even though the last attempts to formulate the ideality of its object. The other two forms of knowledge (know how to live and know how) cannot be concretised only through their singular modes of existence of which is their knowledge of consistence. (trans by author). ${ }^{8}$

The 'savoir-faire' and the 'savoir-vivre' can only be concretised as modes of singularity. This implies that these forms of knowledge cannot be standardised or generalised. For Stiegler, knowledge is always a know-how-to- bifurcate, knowledge produces something new. ${ }^{9}$ The question of automatisation is inherently linked to the 'know how' where forms of 'know-how' can be broken down into discrete repeatable units (actions). The ability to discretise the 'savoir théorique' into forms of reason that can be calculated has a long history within question of knowledge construction as forms of epistemology. But more recently the threat of automatisation of theoretical knowledge has led to discussions in relation to the end of theory (Andersen, 2008). Another aspect of this distinction between 'know how' and 'know what' is within the history of philosophy, this could be understood as an epistemological distinction that can be dated back to Kant's epistemology. ${ }^{10}$ However, for Stiegler the 'savoir vivre', which is somewhat lost in the English translation of 'know how to live', is beyond the mode of calculability, it cannot be grammaticised, ${ }^{11}$ discretised and therefore remains beyond modes of replication in tertiary retention. The richness of the term 'savoir vivre' in French is within the semantic layering of socialisation and subjectivisation ${ }^{12}$ that this the term 'holds, 'knowing how to live',' how to take 'pleasure in life',' knowing 'how to be'. The disruption to these knowledges and the processes of education has for Bernard Stiegler as sense of real urgency; the urgency is reflected in his recent publications where the question of the impact of the disruption is now being recognised on a planetary scale (Stiegler, 2016).

The ability to grammatise or discreditise the 'savoir-faire' has a different genealogy and it can be dated by to an activity which accompanies the industrial revolution. The grand project of Diderot's Encyclopedia (1751), which is an encyclopedia of knowledge, gives ample examples of 
how the 'savoir-faire' can be broken down into discrete elements as modes of production. Diderot gives detailed accounts of the knowledge that craft workers had and the processes they used. Of course, discretisation will lead to the loss of knowledge (proletarianization) once the discrete gestures are repeated in isolation. In Marx's analysis in part one of Capital it is this ability to replicate the gestures in isolation which will lead to the development of the manufacturing base of the industrial revolution. ${ }^{13}$ For Bernard Stiegler the loss of 'savoir-faire' is part of the tragedy of the twenty-first century, where automatic processes attempt to replace any of the 'savoir-faire' which is left including transmission of knowledge. It is the relationship between automatisation of 'savoir-faire' which will lead to job losses. The development of new forms of data analytics as forms of deep learning algorithms are seen as threats to the very reasoning processes themselves (Andersen, 2008). This raises questions in relation to what is understood as theoretical knowledge and reason, reason in the Kantian sense, is beyond theoretical knowledge and it is a form of analysis and synthesis, the theoretical knowledge of information is a form of systemic stupidity (Fitzpatrick \& Kelleher, 2018) that can be automated but not reason. The question of reason, which was the project of the enlightenment, has become more pressing today as modes of replication of reason are understood as forms of artificial intelligence.

The question of education and the responsibility of the university within the age of the Anthropocene has becomes central for Bernard Stiegler. This is reflected in the latest publication (Qu'appelle-t-on Panser 2018) which deals with the question of the Anthropocene and posting fundamental questions in relation to care and education: education as care of the other, care of the planet and care of the self. In addition, to questions of care and the Neganthropocence is the analysis of what has led to the Anthropocene. According to Stiegler the question of the Anthropocene is intrinsically linked to question of entropy and negative entropy, this analysis is based not simply on Schrodinger's understanding of negative entropy in Forms of Life (1945), as that thing which keeps us alive and not become inert dead matter, but also based on entropy from information theory of Shannon and Wienner. According to Stiegler Marx and Engles did not forsee the relation between proletarianisation and entropy:

But this is what Marx and Engels were not yet able to see, nor were they able to draw all the consequences, including, in particular, the fact that, before anything else, proletarianization is a process that entails a colossal increase of entropy (p. 243, Age of Disruption)

In addition, Stiegler's understanding of negative entropy is based contemporary research in biology and mathematics into anti-entropy a term coined by Longo and Bailly to describe the negative inverse aspects of entropy (Bailly \& Longo, 2009) or what Dan Ross as referred to as counter-entropy (Ross, 2018). Therefore, the task for education is to find ways to reverse the forces which have led to the Anthropocene, these new ways, therefore, have to be neganthropic. The entropic processes are also linked to questions of dissipation of energy and of dissipation of attention. The development of the world, wide, web in the mid-90s and the development of the smartphones in 2006 and social media (facebook) in 2006 have led to a rapid increase of the dissipation of attention, this could also be considered to be an entropic process. These are all forms of disruptions of attention.

Bernard Stiegler in Dans la Disruption (2016) states that the disruption 'est ce qui va plus vite que toute volonté, individuelle aussi bien que collective' (p. 24). \{that which goes faster than all will, individual as well as collective will\}. The point that Stiegler makes here is that the speed of technological change is faster than collective or individual will. Stiegler's analysis of these processes builds on the work of Gilbert Simondon in relation to the psychic, collective and technical individuation. These processes of individuation are short circuited by forms of tertiary digital retentions, the very process of becoming human, individuating and collective individuation are disrupted by forms of technical short circuiting. To take an example, ${ }^{14}$ the communication between parents and their infants is disrupted by parenting with smartphones, where the smartphone acts as a mode of entertainment - a mode of distraction. The ability to transfer 
knowledge, intergenerational knowledge, is profoundly disturbed by the intersection of the communication process, where the unconditional regard of parenthood is disrupted. The smartphone becomes a transitional object with inbuilt modes of distraction, or to put it differently, inbuilt modes of inattention, where attention is harnessed in a very particular way. The harnessing of attention is always based on an economic exploitation, where the consumer becomes producer of value through the data generated by according their attention. However, there is something fundamentally different with the development of recent forms of tertiary retention: smartphones, social media, news feeds on twitter, these forms of tertiary retentions which are digital objects that are omnipresent form of our waking and sleeping hours, now operate at speeds beyond our human neurological capacity.

These technologies or hyper technologies transfer information at speeds that are beyond our own neurological speeds; therefore, beyond the speed of human information flow: the speed it takes for information to pass through our own neurons has been surpassed by the speed of computational information transmission (Hayles, 2017). Katherine Hayles, in her recent publication, refers to these new forms of computation as a form of nonconscious cognition, where the speed of the transfer of cognition which is a thousand times faster than our ability to be conscious of it. This is the speed of computation. A speed beyond the speed of our perception or aperception and therefore beyond our mechanisms of attention. For Katherine Hayles the computation interfaces through the screen enable a form of hyper-attention. ${ }^{15}$

Deep attention, the cognitive style traditionally associated with the humanities, is characterized by concentrating on a single object for long periods (say, a novel by Dickens), ignoring outside stimuli while so engaged, preferring a single information stream, and having a high tolerance for long focus times. Hyperattention is characterized by switching focus rapidly among different tasks, preferring multiple information streams, seeking a high level of stimulation, and having a low tolerance for boredom. (Hayles, 2007, p. 187).

The forms of inattention or hyper inattention which are now prevalent in our epoch are leading to disastrous consequences, where, for example, there has been a rapid increase in diagnosis of Attention Deficit Hyperactivity Disorder (ADHD), and following on from the Diagnostic and Statistical Model of Mental Disorders 5 the recognition of internet addiction as a mental illness. ${ }^{16}$ Nonetheless, this should not be simplified into a correlation between negative effects of digital technologies and hyper-attention. Hyper attention is also a mode of multi-tasking and multiple attention activities ${ }^{17}$ and it should not be oversimplified into paper versus screen or younger versus older generation. However, if there is an increased awareness of ADHD and the use of gaming there is also increased correlation between the two. ADHD is multifaceted neurological disorder, and the diagnosis is based on a number of functions, however it could be argued that the use of digital technologies is exasperating the distractibility of children. Katherine Hayles argues that the digital interfaces themselves act as forms of hyper-attention or hyper-reading where the readers flips from one form of written text to the next, from webpage to webpage, pdf to pdf never allowing a form of deep reading of the text, scanning, scrolling, swiping through textual production on screen. ${ }^{18}$ This generation of children in the US who seem unable to concentrate because of hyper-attention is, sometimes, referred to as the Ritalin generation, the name of the pharmacological product prescribed by clinicians for children who present with hyper attention difficulties, the level of prescription of Ritalin has increased dramatically over the last number of years. ${ }^{19}$ Indeed, the analysis of attention and distraction in the work of Mary Anne Wolf (2017) demonstrates the neurological impact of the digital technologies on the very substrate of the brain, where, there is a fundamental difference between the digital reading brain where the modes of inattention are hard wired into the neurological pathways. The inbuilt inattention or distraction of the digital interface is something which is having a huge impact in the classroom but also in the pre-school years (see Fitzpatrick, 2013). The modes of inattention or capturing of attention through tertiary digital technologies have now become a huge issue for society and the act of parenting with attention seeking distractive technologies needs close 
attention. There is, however, a difference in the analysis of the 'becoming human' in and through technology between Stiegler and Hayles. Katherine Hayles through her development of the concept of technogenesis points to the co-evolution of technology and humans whilst for Stiegler the pharmacological nature technology in this co-evolution needs to be taken into account (Halyes, 2012).

\section{Part two: the pharmacological - neganthropic}

The challenge, therefore, is to explore the positive pharmacology, the truly pharmacological nature of these technologies, according to Stiegler this pharmacological exploration takes place through processes of organology. There are two aspect to the organological approach, firstly, understanding the evolution of technology and secondly understanding the nature of that evolution, through processes of psychic, collective and technical individuation. This section will explore the interrelation between grammatisation and loss of knowledge. However, in order to do so it is necessary to identify how within Stiegler's analysis there is an inherent relation between grammatisation, pharmacology and proletarianisation. Bernard Stiegler offers a very detailed and exhaustive account of the pharmakon and phamaka and pharmakos throughout a number of his publications, but it is only with the publication of Ce qui vaut la peine d'être vécue, de la pharmacologie in 2010 that Stiegler sets out a complete analysis of the positive element of the pharmakon. Daniel Ross has referred to this as Stiegler's organological and pharmacological phase where the question of attention and protention are central to the development of the analysis technology within our epoch which is in collective existential crisis. $^{20}$

Nevertheless, for our purposes the questions of attention and protention are embedded within the development of the concept of positive pharmacological. The question of pharmacology has its origins in the work of Jacques Derrida and in particular the text which acts as a shift from the project of grammatology to deconstruction, 'La pharmacie de Platon' published in $1967 .^{21}$ In this article, we do not have the space to detail the entire argument, however, in Plato's Pharmacy Derrida sets out of the main tenant of the shift towards deconstruction (Fitzpatrick, 2015). As Bernard Stiegler points out, whilst, Derrida sets out to give an exhaustive deconstructive account of the pharmakon, both its toxic, nefast and dangerous aspects as well as the curative, virtuous and positive aspects he never really develops the positive aspects: 'Derrida never envisaged the possibility of a pharmacology, that is to say a discourse of the pharmakon apprehended in the curative and toxic dimensions in the same gesture'.22 Jacques Derrida sets out at the beginning of the text the double role of the remedy and the poison within the Phaedrus, nonetheless, he under emphasises the positive elements of the pharmakon.

\footnotetext{
We hope to display in the most striking manner the regular, ordered polysemy that has, through skewing, indetermination, or overdetermination, but without mistranslation, permitted the rendering of the same word by "remedy", "recipe", "poison", "drug", "philter", etc. It will also be seen to what extent the malleable unity of this concept, or rather its rules and the strange logic that links it with its signifier, has been dispersed, masked, obliterated, and rendered almost unreadable not only by the imprudence or empiricism of the translators, but first and foremost by the redoubtable, irreducible difficulty of translation. (Derrida, 1981, p. 77).
}

For Derrida the pharmakon which Socrates refers to in relation to writing is comparable to a drug $^{23}$ and it is this relation to substance as drug which is at centre of Stiegler's revisiting of the question of the pharmakon. The first form of the pharmakon is the invention of writing, writing, according to Plato, leads to a loss of knowledge while at the same time acting as a placeholder for knowledge. This tension between writing which acts as a form of knowledge construction and as a form of knowledge destruction is at the centre of the term mobilised by Plato: writing as a pharmakon. ${ }^{24}$ The loss of knowledge is referred to in relation to forms of memory, for Plato true memory is that of 'anamnesis' whilst the regurgitative simple repetition of memory is 'hypomnesis', writing is rejected by Plato as form loss of memory as 'hypomnesis'. 
The fact is that this invention [writing] will produce forgetfulness in the souls of those who have learned it because they will not need to exercise their memories [...], being able to rely on what is written, using the stimulus of external marks that are alien to themselves [...] rather than, from within, their own unaided powers to call things to mind [...]. So it's not a remedy for memory, but for reminding, that you discovered (oukoun mnẽmẽs, alla hupomnẽseõs, pharmakon hẽures). And as for wisdom [...], you're equipping your pupils with only a semblance [...] of it, not with truth. (Plato, 370 BC/1985, 274e-275b, cited in Derrida, 1981, pp. 104-105, emphasis in original).

For Plato writing will enable the loss of knowledge by producing noetic forgetfulness, the exteriorisation of memory in the external marks (written alphabet) is opposed to internal recalling without the external traces. Writing as pharmakon, functions both as a placeholder for memory and as a form of protention, projecting into the future. Attention, for Bernard Stiegler, is linked to modes of retention or to put it simply, modes of memory and the distinction between true memory and regurgitation memory are linked to modes of attention. The deconstructive reading attempts to overcome the binary opposition between anamnesis and hypomnesis by pointing to the ambiguity of this relation, and it is here that the question of the supplement can also be raised. Anamnesis and hypomnesis are embedded in each other, one cannot exist without the other, hypomnesis enables anamnesis and they should not be considered in opposition to each other. Writing, therefore, acts as placeholder for memory, an exteriorised trace outside of the body, an exosomatic trace, which is a tertiary retention.

That said the pharmakon constitutes one aspect of the proletarianisation of spirit (the loss of knowledge) just as the tool-machine prolentarianised the body of the worker producers (took away their know how)'. Trans by author $)^{25}$

For Stiegler the pharmakon (which is writing) enables the loss of knowledge, which is the proletarianisation of the spirit. Stiegler extends to all forms of the machine-tool proletarianisation, the loss of knowledge (here understood as 'know how') which takes place through the industrialisation and automatisation of labour. Nevertheless, in order to make this shift from writing as pharmakon as a form of proletarianisation of the noetic soul to the loss of knowledge through industrial manufacturing process where the gesture of the labourer is replicated in the machine tool it is necessary to explore Stiegler's analysis of the concept of grammatisation.

The term grammatisation originates from the work of Sylvain Auroux, in La Révolution Technologique de la Grammatisation, 1994, which Stiegler will extend and develop into a process of grammatisation. In this book Auroux makes a connection between writing and epistemology - epistemology of sciences. There are two elements to the analysis of writing, first, according to Auroux it enables reflection on language, a form of metalanguage and secondly, it is a unique development in the history of humanity as a form of 'tool'. Hence, in the title of his book, indicating the extension of the analysis to technology from grammaticisation, forms of instrumentalisation and tools. However, the main tenant of the argument is that speech can be broken down into discrete elements, these discrete elements are the forms given in alphabetic writing. This process of breaking things down into discrete elements is the process of discretisation or grammatisation. For Stiegler, as Daniel Ross points out, this analytical process enables the extension beyond language to other forms of temporal and perceptual flows such as cave paintings which attempt to capture the movement of the gezell to Marcel Duchamps and the woman descending the staircase, where the process of discretisation or grammatisation is captured within the painting itself as form of archi-cinema. The process of grammatisation is something which is profoundly human and is part of our protentional relationship with the world. For Auroux, automatisation is enabled by grammatisation and it is the interrelation between the discrete and the automatic which Stiegler will develop. However, the process of discretisation or grammatisation has for consequence the reduction of the being in the world to discrete, measurable and therefore, calculable objects. By extending the concept of grammatisation beyond its strictly linguistic and epistemological of science origins in the work Auroux, Stiegler can expand the notion of pharmacology. The grammatisation of speech in writing leads to new forms of knowledge (such 
as the written law) and to loss of knowledge - loss of memory, this is the ambiguity of the pharmakon to both act as cure and poison, to enable and to destroy. With the industrial revolution there is another huge shift in society as gestures of the labourer are grammatised and replicated by the machinic process of manufacture. Within Stiegler's analysis the grammatisation of the know-how of the industrial revolution leads inevitably loss of knowledge; it is a process of deprivation of knowledge that takes place. The different forms of knowledge are at risk of proletarianisation, of deprivation: the know-how or work knowledge of the labourer as well as the knowing how to live which make up culture in general, or, indeed, more recently the conceptual theoretical knowledge.

Nonetheless, there is a risk here of reducing Stiegler's analysis to the negative toxic, nefast effects of the pharmakon. Within Stiegler's analysis, in his recent publication, I would argue that the positive possibilities of the pharmakon have become more explicit: the possible remedies, the possible cures are being articulated. The toxic effects of the pharmakon need to be balanced by political powers in order the reign in the toxic effects. These therapeutics are, I would argue, what make Stiegler's analysis more pertinent than other contemporary analyses of our epoch. In the next section we shall turn analysis to what the proposed therapeutics could be in relation to the question of education and attention.

\section{Part three: conclusion the therapeutics}

In Stiegler's analysis the organological study of the evolution of technology as psychic, collective and technical individuation enables the possible re-harnessing of technology to promote reflection, deliberation and new forms of bifurcation. The therapeutics of the pharmakon are possible for Stiegler through modes of care, educare, which includes experimentation as modes of learning in very concrete practical interventions. ${ }^{26}$ The positive pharmacological possibilities which Stiegler has been developing are accompanied by the conceptual development of the term capacitation. The literature that Stiegler refers to develop the notion of capacitation is from the work of Amartya Sens, where capacitation, or the capability approach, attempts to move beyond the notion of wealth or richness in terms of monetary value. ${ }^{27}$ As Stiegler states in the $L a$ Disruption (2016) that the neganthropic 'disruption will be the foundation of a new political economy based on capacitation which is deproletarianisation'. ${ }^{28}$ The creation of a new political economy has to take place at the level of the state and the internation, it is only through the intervention at internation level that the question of the political economy can be raised. In his 2015 publication Automatic Society and the future of work, Stiegler sets out a series of propositions around neganthropic solutions, the principle one is a form of contributive economy which builds on Amartya Sens analysis of capacitation but importantly develops the analysis of the intermittence and otium (leisure time).

The concept of intermittence has both a philosophical genealogy, in terms of the intermittence of the soul, the soul is noetic temporally, therefore, intermittently and as a very practical mode of action in the world as a form of political economy. In France, Belgium and the Netherlands, the cultural workers can obtain a particular status, for example, under French law it is entitled Intermittant de spectacle. This status has the advantage of enabling a distinction between employment and work. For example, a theatre lighting specialists has an employment contract for a number of hours per week, whereas the work can take place throughout the entire week. This is a fundamental distinction where employment, labour and work can be distinguished. Work (oeuvre) is not the same as labour, labour is something which can be grammatised, discretised but not work which is understood as open ended. Work, taking the French meaning of Oeuvre (open/opening), is constantly open to the new bifurcations, ${ }^{29}$ new developments. In parallel, therefore, to a distinction between work, employment and labour is the 
development of the concept of contribution, contributing to the overall well-being of the planet as forms of negative anthropocentric gesture what Bernard Stiegler refers to as an neganthropic.

It is possible to use the automatisms for the service of reason, that is to say decisions, hence individual time for participation in the formation of a both historic and political time- that is understood, projected collectively and neganthropic. ${ }^{30}$

The future of work within an automatised society is hence a project of collective ambition to put the tertiary retentions of digital technologies to the service of reason. At a fundamental level, the ability to harness the digital technologies for decision-making processes is not to be misread as the incorporation of data science into decision making processes but the acceptance that digital technologies enable forms of decisions. The presuppositions and presumptions of those decision making processes leads to understanding that the data itself is not neutral or objective (Kelleher, 2018) and the process of interpreting the presumptions of the technologies is kernel to the ability to harness the positive pharmakon.

In terms of Higher Education the positing of the process of positive pharmacology or the introduction of the therapeutic can be seen through the development of forms of neganthropic pedagogic gestures, one could argue that they are akin to the neganthropic aesthetic gestures which brings to the fore the singuarlities which cannot be grammatised, discretised. However, the process of translating the possible therapeutics into pedagogy and the action of education is more challenging. It is possible to point to examples of particular instances within the education process where the individual pedagogic gesture enables a form of reasoning beyond the reductionist calculation. This could be similar to the development of critical thinking across all the programmes, or introducing science technology studies into engineering programmes. Nonetheless, this would be a reductive reading of the what potentials of therapeutics could be whether these examples are therapeutics or not would depend on how they are introduced, actioned within the pedagogical approach. However, when within Higher Education we see numerous examples of the hegemonic market whether this be in terms of the curriculum design process themselves or more obviously with the push for the roll out of student analytics as modes of governance within Higher Education. Therefore, as Stiegler points out, it is the very role of the university which is at stake in the twenty-first century where education is seen as a form of economic agency, and where the economic agency dictates the form of and shape of the curriculum itself.

As he states in States of Shock

The programme of the future university must, as a priority, serve a politics of de-proletarianization, and struggle against the process of dis-apprenticeship, of unlearning. It must fight against the destruction of cognitive functions and the short-circuiting of reason in which rationalization has consisted, as a toxic becoming induced by the pharmacological character of reason in the industrial context. (p. 173)

From this citation there is an emphasis on the role of the University within the context of the industrial environment and it here that that the challenge lies. The challenge is both one of understanding what is at stake in the process of unlearning and de-proletarianisation and the development of modes of curriculum design which set out to de-proletarianise and promote reason.

Whilst there is a pressing need to re-harness the University itself as a mode of social and political agency in order to do so there is a need to develop social and political possibilities at an international level and this is something towards which Stiegler has begun to turn his attention with the development of the concept of internation, extending the analysis of Marcel Mauss. ${ }^{31}$ The example of curriculum design in the twenty-first century is moot point at the moment, if in the traditional sense of curriculum design, programmes are designed in a short term relation to the labour market where the jobs of today may not exist in the near future then the role of designing curriculum with certification of the job market becomes outmoded. There is a misalignment between the objectives of the curriculum to provide people for employment within 
specific job sectors and the modes of employment within society. The curriculum, therefore, needs to take into account the aspects of socialisation and subjectivisation or capacitation.

The therapeutics that are emerging within Stiegler's work and the research of a number of initiatives can be broken down into two separate groupings, the first one is the project of Digital Studies network, secondly Contributive Research. The Digital Studies Network is investigating the pharmacological and organoloy of Digital technologies: positive and negative impacts on epistemologies of disciplines and on aesthetics as modes of cultural production shift. The term itself Digital Studies is used to differentiate itself from Digital Humanities: Digital Studies is applicable to all disciplines, as all disciplines are being impacted by the creation of black box technologies. The project of Digital Studies sets out to chart and analyse the negative impacts of the development of specific forms of knowledge production within the disciplines themselves. The concept of contributive research holds the premise that everyone is a researcher and not simply an object of research, the opening of research to other forms of enquiry which are not just driven by short term instrumentalised mediocracy of funding agencies. Within the development of contributive research other forms of enquiry are mobilised, these other forms of enquiry can be practice-based research within the creative arts or socially engaged art practice methodologies.

The development of Digital Hermeneutics also point to new modes of deliberation, new modes of interpretation that could be harnessed to enable unlearning to be overcome. The initial promises of the web of Time Berners Lee and in particular the semantic web have not come to fruition. The creation of meaning has not happened in the ways which were originally set out, and therefore, there is a need to re-harness the potential of meaning making and Stiegler has referred to this a form of hermeneutics of the web. The forms of semantics referred to as the semantic web, where meaning could be generated computationally have failed, the kernel issue here is what cannot be captured, knowledge cannot be reduced to the computational treatment of information. In other words language cannot be simply reduced to natural language processing and or natural language generation. The question of what cannot be captured resides in the forms of innovation, disruptions, which are bifurcations, idiosyncrasies which lie outside the computational processes.

The language models which underpin all natural language processing technologies are models which are by their very essence forms of averaging, flattening out or standardisation of language. However, meaning creation or language itself is always based on the idiom or the idiosyncratic, the ability to create new forms of meaning within the processes of enunciation itself is central to language. In order to implement the positive pharmacological new forms of innovation and interpretation are needed which are beyond the realms of Digital Humanities. The proposition would be that instead of the presupposition of the computers generating meaning (the semantic web) the generation of meaning is held by forms of individuation and forms of bifurcation which can never be captured or calculated.

The term Digital hermeneutics refers to the ability of digital technologies to enable a layering of multiplicity of interpretation allowing for new readings to emerge through the different digital layering. Digital hermeneutics recognises the macroscopic possibilities of corpus linguistics and natural language processing but also recognises the locality of the idiom is also necessary, the microscopic reading of the individual instance of the idiom. Hermeneutics in this sense would include the more mischievous sense of Hermes, which is different to the story of Hermes of the Homeric tradition that sees Hermes as guardian of the God of messages and messenger but Hermes who disturbs and disrupts the status of interpretation, to revisit or to unveil the presuppositions, presumptions of the sedimented understandings. This is a form of radical hermeneutics which enables a multiplicity of interpretations, a multiplicity of possible interpretations (Caputo, 2018). This re-harnessing of digital tertiary retentions allows for the positive pharmacologies, the positive harvesting of attention in order to enable reflection rather than to destroy attention by harvesting solely for monetary means. In order to do re-harness digital technologies, the singularity of gesture, be that the gesture of dance, music, painting, sculpture, or thought need to 
flourish as new forms of innovation and new forms of bifurcations. These positive pharmacologies or therapeutics of new knowledges are what is at stake for the university of the twentyfirst century.

The possible therapeutics range, therefore, from the process of meaning making as hermeneutic process -to re-enable through the use of delibertative technologies where the reader, viewer is demanded upon to bifurcate meanings-, to the process of curriculum design itself, where the curriculum of the new university takes into account the anti-entropic, as new forms of neganthrology. The designing of a new curriculum which takes into the organology of the Anthropoence and allows for the development of new modes of capacitation and knowledge production is the challenge of the twenty-first century. The implementation of such a curriculum to re-harness the systematic and collassal entropic process of the contemporary digital technologies is a huge task and one which requires that Higher Education takes responsibility for it.

\section{Notes}

1. The research for this article comes from the Marie Sklodowska Curie RISE project, The Real Smart City (see realsms.eu). This project has received funding from the MSCA-RISE programme under grant agreement No. 777707.

2. "The intentionality proper to primary memory presents the past; the intentionality proper to secondary memory re-presents it (Husserl 1964, p. 101).

3. See Stiegler, B. Technics and Time Vol. 1. gives an analysis of Husserl's distinction between primary and secondary retention.

4. See Stiegler, The Age of Disruption, p. 6.

5. ... la mission des universités est de reconstruire de l'attention profonde à l'époque des technologies que met en oeuvre le système mnémotechnique mondial au sein duquel ces psychotechnologies, hégémoniquement soumise au marketing, produisent des effets massivement toxiques. p. 276.

6. In The Age of Disruption, pp. 15-16.

7. For a critic of the economy of attention see Citton (2017).

8. Je parle ici de toutes les formes de savoir: savoir-vivre, savoir-faire et savoir théoriques, bien que seuls ces derniers tentent de formaliser l'idéalité de leurs objets. Les deux autres formes de savoir (les savoir-vivre et savoir-faire) ne peuvent concrétiser que par des modes d'existence singuliers leurs savoirs de consistances $p$. 226, La Misère Symbolique.

9. The Semantic web cannot in anyway produce knowledge. Knowledge is always to bifurcate knowledge that is to say a proof of non-knowledge capable of creating through a new cycle of images (i.e. say from new dreams), a new circuit of in the process of transindividuation in which all knowledge consists (author trans). 'Le web sémantique ... ne peut en aucun cas produire du savoir. Un savoir, c'est toujours un savoir-bifurquer, c'est- - a-dire une epreuve du non-savoir capables d'engendrer à travers un nouveau cycle des images (c'esta-dire a partir de nouveaux rêves) un nouveau circuit dans le processus de transindividuation en quoi tout savoir consiste'. La Société Automatique, p. 263.

10. See Kant, I. The Critique of Pure Reason, introduction. A distinction between theoretical reason and practical reason.

11. We shall return to the question of grammatisation in the next section.

12. See Gert Biesta (2014) distinction between subjectivisation and socialisation, in Beautiful Risk of Education (Interventions: Education, Philosophy, and Culture).

13. Karl Marx, Capital -

14. This example is taken from on-going research with the institut de rechercher et innovation and pleine commune is part of the Marie Sklodowska Curie Actions RISE 777707 Real Smart City see realsms.eu for further details.

15. The analysis of digital reading and the pharmakon are developed much more fully in a book chapter published in 2013 (Fitzpatrick, 2013).

16. The author would like to thank Geraldine Brosnan at Lucena Clinic, Saint John of God Community Mental Health Services Mental Health Services in Dublin for her comments in relation to the usage of Ritalin and young children with ADHD. This clinic has carried out some very interesting research into nonpharmacological modes of intervention using methodologies based on communication - this therapy addresses emotional regulation and social communication skills using a game called the secret agent society from Australia.

17. Whether inclined toward deep or hyper-attention, toward one side or another of the generational divide separating print from digital culture, we cannot afford to ignore the frustrating, zesty, and intriguing ways in 
which the two cognitive modes interact. Our responsibilities as educators, not to mention our position as practitioners of the literary arts, require nothing less (Hayles, 2007, p. 198).

18. Gillian Rose, has recently developed the term hyper-seeing in relation to have users flip and swipe from one image to the next on instagram, a form of hyper-seeing of images.

19. De la Pharmacologie p. 49 'Each time there is a dependency or addiction, there is a pharmacological situation which makes it possible, the loved one does is not constituted as an object of desire by becoming itself a sort of pharmakon, surrounded by pharmaka which are the fetished objects'. trans by author.

20. Daniel Ross, Introduction to the Neganthropocene, 2018, p.22.

21. Within the History of contemporary philosophy, the differing and deferring of meaning which the term of difference holds is set against the phonocentricism of presence. La pharmacie de Platon gives a close reading, as Simon Critchley argues, a pedagogic gesture of close readings unveil the relationship between Plato and the Myth of the birth of writing. La Pharmacie de Platon, acts as the turning point within Derrida's philosophical project from the early texts on grammatology to a shift in focus to deconstruction. Whilst the explication of the term deconstruction is not found in the text la pharmacie de Platon, the text itself acts an example of deconstruction, the term pharmakon itself demonstrates how the binary opposition of cure and poison is held in one and the same term.

22. Ce qui fait que la vie vaut la peine d'etre vecue, De la Pharmacologie, 2010, p. 16.

23. For Derrida the substantive nature of the pharmakon is important : 'Le Pharmakon serait une substance, avec tout ce que ce mot pourra connoter, en fait de matière aux vertus occultes, de profondeur cryptée refusant son ambivalence à l'analyse, préparant déjà l'espace de l'alchimie, si nous ne devions en venir plus loin à la reconnaître comme l'anti-substance elle-même: ce qui résiste à tout philosophème, l'excédent indéfiniment comme non-identité, non-essence, non-substance, et lui fournissant par la même l'inépuisable adversité de son fonds et son absence de fond.' (p. 87).

24. Paul Ricoeur (2004) also gives a very detailed account writing as pharmakon, but in Ricoeur's analysis the writing of the archive or writing as the archive becomes a key aspect to his argument which is radically different to what Bernard Stiegler is proposing.

25. 'A cet égard, le pharmakon constitue un facteur de prolétarisation de l'esprit (de perte de savoir) tout comme la machine-outil prolétarisera les corps des ouvriers producteurs (les privera de leur savoir-faire). p. 40, Ce qui fait que la vie vaut la peine d'etre vecue, de la pharmacologie, 2010.

26. The project of 'Territoire Apprenant Contributive de Plaine Commune'\# is an example of one such activity, where the organisation Ars Industrialis and the research unit Institute de Recherche et Innovation acts an interpreter, translator into praxis of the possibilities of care. The european projects MSCA RISE Real Smart Cities\# 777707 and Next Leap\# also demonstrate an international perspective on the development of forms of therapeutics in relation to privacy, annotation and the challenges of smart city technologies. All of these initiatives are framed within the overarching thematic of Digital Studies which sets out to investigate the impact of Digital Studies on the construction of knowledge within disciplinary epistemology and the impact on cultural production or aesthetics. see https://digital-studies.org/wp/en/

27. Sen (2003). 'Countries with high GNP per capita can nevertheless have astonishingly low achievements in the quality of life, with the bulk of the population being subject to premature mortality, escapable morbidity, overwhelming illiteracy and so on'.

28. p. 123, soit ce que j'appelle ici la disruption ... allait conduire a une nouvelle économie politique, fondée sur la capacitation, c'est-à-dire la deprolétarisation.

29. Whitehead, the production of bifurcations as a production of reason. Production of things which cannot be calculated.

30. La Societe Automatique, p. 405 trans by author.

31. Age of Disruption (p. 431).

\section{Disclosure statement}

No potential conflict of interest was reported by the author.

\section{Notes on contributors}

Noel Fitzpatrick is Professor of Philosophy and Aesthetics at the Technological University Dublin, the Dean of the Graduate School of Creative Arts and Media (GradCAM), and Head of Learning and Research Development at the College of Arts and Tourism at the Dublin Institute of Technology. He teaches Philosophy and Aesthetics and supervises Post-Doctoral and PhD students at GradCAM in the College of Arts and Tourism. Noel also gives seminars on phenomenology, hermeneutics, philosophy and technology at the Graduate School. He is a leading member of the European Artistic Research Network, SHARE, and the European Society of Aesthetics. He is regularly 
invited to speak and host seminars internationally. Noel is a leading member of the Digital Studies network (with Bernard Stiegler) at the l'institut de recherche et innovation (IRI) at the Centre Pompidou, Paris. He has also acted as a curator and recently co-curated the 2017 Utopia of Access GradCAM@research pavilion during the Venice Biennale 2017. He is the coordinator of the Marie-Curie RISE Real Smart Cities project. He is co-curator of the Archipelagic Thinking Event in Guayaquil, Galapagos Islands, Ecuador July 2019 and the Archipelagic Thinking @ research Pavilion during the Venice Biennale August 2019.

\section{References}

Andersen, C. (2008). 'The end of theory, the data deluge makes the scientific method obsolete. Wired. Retrieved from https://www.wired.com/2008/06/pb-theory.

Bailly, F., \& Longo, G. (2009). Biological organisation and anti-entropy. Journal of Biological Systems, 17(1), 63-96. doi:10.1142/S0218339009002715

Biesta, G. (2014). Beautiful risk of education (interventions: Education, philosophy, and culture). Paradigm publishers, Boulder Co.

Caputo, J. D. (2018). Hermeneutics: Facts and interpretation in the age of information. London: Penguin Random House.

Citton, Y. (2017). The ecology of attention. Cambridge: Polity Press.

Derrida, J. (1981). Disseminations. Chicago: University of Chicago Press.

Diderot. (1751). Encyclopedia, or a Systematic Dictionary of the Sciences, Arts, and Crafts. Retrieved from http:// encyclopedie.uchicago.edu/.

Fitzpatrick, N., \& Kelleher, J. (2018). On the exactitude of big data: La Bêtise and artificial intelligence (Vol. 7). La Deluziana, December.

Fitzpatrick, N. (2013). Digital reading: A question of prelectio? In C. Fowley, C. English, \& S. Thouësny (Eds.), Internet research, theory, and practice: Perspectives from Ireland (pp. 1-16). Dublin: Research-Publishing.Net

Fitzpatrick, N. (2015) Introduction to Bernard Stiegler interview 'deconstruction and aesthetics', December 2013, InPrint 3(1), Article 4.

Husserl, E. (1964). On phenomenology of consciousness of internal time. Indiana: Indiana University Press.

Hayles, K. (2017). Unthought: The power of the cognitive nonconscious. Chicago: University of Chicago Press.

Halyes, K. (2012). How we think: Digital media and contemporary technogenesis. Chicago: University of Chicago Press.

Kant, I. The critique of pure reason.

Kelleher, J. (2018). Data science. Boston: MIT Press.

Moran, D. (2000). Introduction to phenomenology. London: Routledge.

Paul, R. (2004). In History, Memory Forgetting. Chicago: The University of Chicago Press.

Ross, D. (2018). 'Carbon and Silicon: Contribution to an Elemental Critique of Political Economy (2018). Accessed Carbon and Silicon: Contribution to an Elemental Critique of Political Economy. November, 2018.

Sen, A. (2003). Development as Capability Expansion. In: Fukuda-Parr S, et al. (Eds.), Readings in human development. New Delhi and New York: Oxford University Press.

Stiegler, B. (1998). Technics and time, 1: The fault of epimetheus. Trans. Richard Beardsworth and George Collins. Stanford: Stanford University Press.

Stiegler, B. (2009). Technics and time, 2: Disorientation. Trans. Stephen Barker. Stanford: Stanford University Press. doi:10.1086/ahr/105.1.259

Stiegler, B. (2011a). For a new critique of political economy. Trans. Daniel Ross. Cambridge: Polity.

Stiegler, B. (2011b). Technics and time, 3: cinematic time and the question of malaise. Trans. Stephen Barker. Stanford: Stanford University Press.

Stiegler, B. (2016). Automatic society, volume 1: The future of work. Trans. Daniel Ross. Cambridge: Polity Press.

Wolf, M. (2007). Proust and the squid: The story and science of the reading brain. USA: Harper Collins. 